\title{
PRAVADOLINE SYNTHESIS USING AN IMIDAZOLIUM-BASED IONIC LIQUID AS A GREEN SOLVENT
}

\author{
Phan Thanh Son Nam, Le Vu Ha \\ University of Technology, VNU-HCM \\ (Manuscript Received on May 13 ${ }^{\text {th }}$, 2011, Manuscript Revised November $01^{\text {st }}, 2011$ )
}

\begin{abstract}
An easily accessible ionic liquid, 1-butyl-3-methylimidazolium

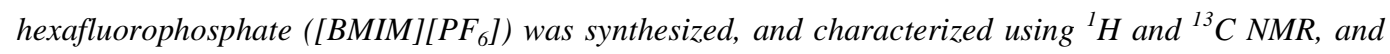
$M S$. The ionic liquid was demonstrated to be an efficient green solvent for the synthesis of pravadoline, one of non-steroidal drugs. High yield was achieved without the presence of an anhydrous Lewis acid catalyst. The reaction was also successfully carried out using other imidazolium-based ionic liquids, including 1-hexyl-3-methylimidazolium hexafluorophosphate ([HMIM][PF $\left.F_{6}\right]$ ), and 1-octyl-3methylimidazolium hexafluorophosphate ([OMIM][PF $\left.\left.F_{6}\right]\right)$. To our best knowledge, this is the first report in Viet Nam on the synthesis of a pharmaceutical chemical in ionic liquids as green solvents.
\end{abstract}

Key words:

\section{INTRODUCTION}

Pravadoline, being commercialized under the name of Win 48098 by Sterling Drug (Sterling Research Group, Rensselaer, New York), was developed as a new antiinflammatory and prostaglandin synthesis inhibitor, acting through inhibition of the enzyme cyclooxygenase [1]. Pravadoline and more importantly some of its analogues have also been used as a probe for neurochemical receptors, since it has been found to be an agonist of the cannabinoid receptor [1,2]. Ionic liquids have been considered as green alternatives to conventional organic solvents because their non-volatile nature can reduce the emission of toxic organic compounds and facilitate the separation of products from the reaction mixtures $[3,4]$.
A variety of ionic liquids have been investigated, in which dialkylimidazoliumbased ionic liquids exhibit several advantages such as keeping the liquid condition under a wide range of temperature and having excellent solubility for many substrates and molecular catalysts $[5,6]$. We recently reported the use of an imidazolium-based ionic liquid as a green solvent for the reaction between 1- $(N$ morpholino)-2-chloroethane hydrochloride and 2-methylindole to form 1-(2- $(N-$ morpholino)ethyl)-2-methylindole as the principal product $[8,9]$. In this paper, we wish to report for the first time in Viet Nam, to our best knowledge, the synthesis of pravadoline using imidazolium-based ionic liquids as green solvents. 


\section{EXPERIMENTAL}

\subsection{Materials and instrumentation}

Chemicals were purchased from SigmaAldrich and Merck, and used as received without further purification. ${ }^{1} \mathrm{H}$ and ${ }^{13} \mathrm{C} \mathrm{NMR}$ spectra were recorded using a Bruker AV 500 spectrometer. MS spectra were recorded using a Thermo Finigan TSQ7000 triple quadrupole. GC analyses were performed using a Shimadzu GC-17A equipped with a FID detector and a 30 $\mathrm{m} \times 0.25 \mathrm{~mm} \times 0.25 \mu \mathrm{m}$ DB-5 column. GC-MS analyses were performed using a Hewlett Packard GC-MS 5972 with a RTX-5MS column (length $=30 \mathrm{~m}$, inner diameter $=0.25$ $\mathrm{mm}$, and film thickness $=0.5 \mu \mathrm{m})$. The temperature program for GC-MS analysis heated samples from 40 to $300{ }^{\circ} \mathrm{C}$ at $10^{\circ} \mathrm{C} / \mathrm{min}$ and held them at $300{ }^{\circ} \mathrm{C}$ for $5 \mathrm{~min}$. Inlet temperature was set constant at $280{ }^{\circ} \mathrm{C}$. MS spectra were compared with the spectra gathered in the NIST library. HPLC-MS was conducted on a P4000/Spectra physic HPLC coupled with a TSQ7000/ Thermo Finnigan MS.

\subsection{Synthesis of the ionic liquid}

In a typical reaction, $N$-methylimidazole (20.68 g, $0.252 \mathrm{~mol}$ ) and $n$-butyl bromide $(38.13 \mathrm{~g}, 0.278 \mathrm{~mol})$ were added to a $500 \mathrm{ml}$ round-bottom flask equipped with a Dimroth condenser. The mixture was heated intermittently in a modified household microwave oven (Whirlpool M541-800W) at $200 \mathrm{~W}$. After the first heating for $5 \mathrm{~s}$, the irradiation was paused for $1 \mathrm{~min}$, and the reaction mixture was then heated at the same power level for an additional $5 \mathrm{~s}$. The procedure was repeated for a total irradiation time of $1 \mathrm{~min}$. The resulting ionic liquid was then cooled, triturated and washed with diethyl ether $(6 \times 50 \mathrm{ml})$ to remove unreacted starting materials. The solvent residue was then removed by a rotovap at $30{ }^{\circ} \mathrm{C}$, affording 52.93 $\mathrm{g}$ of 1-butyl-3-methylimidazolium bromide ([BMIM][Br]) (95\% yield).

${ }^{1} \mathrm{H}$ NMR (500 MHz, DMSO-d6): $\delta=0.887$ (t, 3H; $\left.\mathrm{CH}_{3}\right), 1.256\left(\mathrm{~m}, 2 \mathrm{H} ; \mathrm{CH}_{2} \mathrm{CH}_{3}\right), 1.770$ (m, 2H; $\left.\mathrm{CH}_{2} \mathrm{CH}_{2} \mathrm{CH}_{3}\right), 3.882$ (s, 3H; $\left.\mathrm{N}-\mathrm{CH}_{3}\right)$, 4.204 (m, 2H; N-CH $\left.H_{2}\right), 7.778$ (t, 1H; N-CH=C), $7.856(\mathrm{t}, 1 \mathrm{H} ; \mathrm{N}-\mathrm{CH}=\mathrm{C}), 9.340(\mathrm{~s}, 1 \mathrm{H}, \mathrm{N}-$ $C H=\mathrm{N}) \cdot{ }^{13} \mathrm{C}$ NMR $(125 \mathrm{MHz}$, DMSO-d6): $\delta=$ $13.173\left(\mathrm{C}-\mathrm{CH}_{3}\right), 18.652\left(\mathrm{CH}_{2}\right), 31.279\left(\mathrm{CH}_{2}\right)$, $35.693 \quad\left(\mathrm{~N}-\mathrm{CH}_{3}\right), \quad 48.357\left(\mathrm{~N}-\mathrm{CH}_{2}\right), \quad 122.172$ $(C=\mathrm{C}-\mathrm{N}), \quad 123.461 \quad(\mathrm{C}=C-\mathrm{N}), \quad 136.435 \quad(\mathrm{~N}-$ $C=\mathrm{N}) . \quad \mathrm{MS} \quad(\mathrm{ESI}): \mathrm{m} / z \quad 139 \quad[\mathrm{BMIM}]^{+}, 357$ $\left[(\mathrm{BMIM})_{2} \mathrm{Br}\right]^{+}$.

A plastic conical flask containing a mixture of [BMIM][Br] (25.10 g, $0.115 \mathrm{~mol})$ and distilled water $(50 \mathrm{ml})$ was immersed in an ice bath for $30 \mathrm{~min}$. Hexafluorophosphoric acid $\left(\mathrm{HPF}_{6}\right) 60 \%(20 \mathrm{ml}, 0.147 \mathrm{~mol})$ and water $(50$ $\mathrm{ml}$ ) were then added dropwise to prevent the temperature from rising significantly. After stirring for $12 \mathrm{~h}$ at room temperature, the upper acidic aqueous layer was separated by decantation and the lower ionic liquid portion was washed with cold water $(10 \times 50 \mathrm{ml})$ until the washings were no longer acidic. The ionic liquid was then heated under vacuum at $60{ }^{\circ} \mathrm{C}$ to remove any excess water, affording $27.32 \mathrm{~g}$ of 1-butyl-3-methylimidazolium

\section{Trang 80}


hexafluorophosphate $\left([\mathrm{BMIM}]\left[\mathrm{PF}_{6}\right]\right) \quad(83 \%$ yield).

${ }^{1} \mathrm{H}$ NMR (500 MHz, DMSO-d6): $\delta=0.905$ (t, 3H; $\left.\mathrm{CH}_{3}\right), 1.262\left(\mathrm{~m}, 2 \mathrm{H} ; \mathrm{CH}_{2} \mathrm{CH}_{3}\right), 1.771$ (m, 2H; $\mathrm{CH}_{2} \mathrm{CH}_{2} \mathrm{CH}_{3}$ ), 3.846 (s, 3H; N-CH $H_{3}$, 4.157 (m, 2H; N-CH $\left.H_{2}\right), 7.668$ (t, 1H; N-CH=C), 7.733 (t, $1 \mathrm{H} ; \mathrm{N}-\mathrm{CH}=\mathrm{C}), 9.071(\mathrm{~s}, 1 \mathrm{H}, \mathrm{N}-$ $C H=\mathrm{N}) \cdot{ }^{13} \mathrm{C}$ NMR $(125 \mathrm{MHz}, \mathrm{DMSO}-\mathrm{d} 6): \delta=$ $13.141\left(\mathrm{C}-\mathrm{CH}_{3}\right), 18.711\left(\mathrm{CH}_{2}\right), 31.276\left(\mathrm{CH}_{2}\right)$, $35.651\left(\mathrm{~N}-\mathrm{CH}_{3}\right), 48.509\left(\mathrm{~N}-\mathrm{CH}_{2}\right), \quad 122.193$ $(C=\mathrm{C}-\mathrm{N}), \quad 123.542 \quad(\mathrm{C}=C-\mathrm{N}), \quad 136.444 \quad(\mathrm{~N}-$ $C=\mathrm{N}) . \quad \mathrm{MS}(\mathrm{ESI}): \mathrm{m} / z, 139$ [BMIM] $^{+}, 423$ $\left[(\mathrm{BMIM})_{2} \mathrm{PF}_{6}\right]^{+}$.

1-Hexyl-3-methylimidazolium hexafluorophosphate ([HMIM] $\left.\left[\mathrm{PF}_{6}\right]\right)$, and 1octyl-3-methylimidazolium hexafluorophosphate ([OMIM][PF 6$])$ were synthesized in a yield of $83 \%$ and $85 \%$, respectively, using a similar procedure.

${ }^{1} \mathrm{H} \quad \mathrm{NMR}$ (500 MHz, DMSO-d6) for [HMIM][PF 6 ]: $\delta=0.873\left(\mathrm{t}, 3 \mathrm{H} ; \mathrm{CH}_{3}\right), 1.272$ (m, 6H; $\left.\mathrm{CH}_{2} \mathrm{CH}_{2} \mathrm{CH}_{2}\right), 1.783\left(\mathrm{~m}, 2 \mathrm{H} ; \mathrm{CH}_{2}\right)$, 3.846 (s, 3H; N-CH $), 4.149\left(\mathrm{~m}, 2 \mathrm{H} ; \mathrm{N}-\mathrm{CH}_{2}\right)$, 7.7665 (t, 1H; N-CH=C), 7.734 (t, 1H; N$\mathrm{C} H=\mathrm{C}), 9.069(\mathrm{~s}, 1 \mathrm{H}, \mathrm{N}-\mathrm{CH}=\mathrm{N}) .{ }^{13} \mathrm{C} \mathrm{NMR}$ (125 MHz, DMSO-d6): $\delta=13.708\left(\mathrm{C}-\mathrm{CH}_{3}\right)$, $21.799\left(\mathrm{CH}_{2}\right), 25.085\left(\mathrm{CH}_{2}\right), 29.266\left(\mathrm{CH}_{2}\right)$, $30.487\left(\mathrm{CH}_{2}\right), 35.651\left(\mathrm{~N}-\mathrm{CH}_{3}\right), 48.789(\mathrm{~N}-$ $\left.\mathrm{CH}_{2}\right), 122.191(C=\mathrm{C}-\mathrm{N}), 123.540(\mathrm{C}=C-\mathrm{N})$, $136.436(\mathrm{~N}-C=\mathrm{N})$. MS (ESI): $\mathrm{m} / z \quad(\%) 167$ $\left[\mathrm{HMIM}^{+}, 479\left[(\mathrm{HMIM})_{2} \mathrm{PF}_{6}\right]^{+}\right.$.

${ }^{1} \mathrm{H} \quad$ NMR (500 MHz,DMSO-d6) for [OMIM][PF 6 : $\delta=0.860\left(\mathrm{t}, 3 \mathrm{H} ; \mathrm{CH}_{3}\right), 1.265$ (m, $\left.10 \mathrm{H} ; \mathrm{CH}_{2} \mathrm{CH}_{2} \mathrm{CH}_{2} \mathrm{CH}_{2} \mathrm{CH}_{2}\right), 1.780(\mathrm{~m}, 2 \mathrm{H}$; $\left.\mathrm{CH}_{2}\right), 3.845$ (s, 3H; N-CH $\left.H_{3}\right), 4.145$ (m, 2H; N-
$\left.\mathrm{CH}_{2}\right), 7.674(\mathrm{t}, 1 \mathrm{H} ; \mathrm{N}-\mathrm{CH}=\mathrm{C}), 7.741(\mathrm{t}, 1 \mathrm{H} ; \mathrm{N}-$ $\mathrm{CH}=\mathrm{C}), 9.076(\mathrm{~s}, 1 \mathrm{H}, \mathrm{N}-\mathrm{CH}=\mathrm{N}) .{ }^{13} \mathrm{C} \mathrm{NMR}$ (125 MHz, DMSO-d6): $\delta=13.870\left(\mathrm{C}-\mathrm{CH}_{3}\right)$, $22.390\left(\mathrm{CH}_{2}\right), 26.085\left(\mathrm{CH}_{2}\right), 28.772\left(\mathrm{CH}_{2}\right)$, $28.841\left(\mathrm{CH}_{2}\right), 30.137\left(\mathrm{CH}_{2}\right), 31.495\left(\mathrm{CH}_{2}\right)$, $36.642\left(\mathrm{~N}-\mathrm{CH}_{3}\right), \quad 50.003\left(\mathrm{~N}-\mathrm{CH}_{2}\right), \quad 121.860$ $(C=\mathrm{C}-\mathrm{N}), \quad 123.641 \quad(\mathrm{C}=C-\mathrm{N}), \quad 137.076 \quad(\mathrm{~N}-$ $C=\mathrm{N}) . \quad \mathrm{MS} \quad(\mathrm{ESI}): \mathrm{m} / \mathrm{z} 195 \quad[\mathrm{OMIM}]^{+}, 535$ $\left[(\mathrm{OMIM})_{2} \mathrm{PF}_{6}\right]$

\subsection{The synthesis of pravadoline}

In the first step, 1-(N-morpholino)-2chloroethane hydrochloride was dissolved into the ionic liquid (solution $\mathrm{A}$ ). $\mathrm{KOH}$ was added to the solution of 2-methylindole in the ionic liquid, and the mixture was magnetically stirred to dissolve the base (solution B). After that, solution A was added dropwise to solution B, and the resulting mixture was then magnetically stirred for $7 \mathrm{~h}$ at room temperature. The 1-(2-(N-morpholino)ethyl)-2methylindole product was extracted into $n$ hexane, and the solvent was then removed by a rotovap at $30{ }^{\circ} \mathrm{C}$. The product was purified by recrystalization to achieve isolated yield, and analyzed by GC-MS, ${ }^{1} \mathrm{H}$ and ${ }^{13} \mathrm{C}$ NMR.

${ }^{1} \mathrm{H}$ NMR (500 MHz, acetone-d6): $\delta=2.459$ $\left(\mathrm{m}, 4 \mathrm{H}, \quad\left(\mathrm{CH}_{2}\right)_{2} \mathrm{~N}\right), 2.467\left(\mathrm{~s}, 3 \mathrm{H} ; \mathrm{CH}_{3}\right)$, 2.643(m, 2H, $\left.\mathrm{CH}_{2} \mathrm{~N}\right), 3.590\left(\mathrm{~m}, 4 \mathrm{H},\left(\mathrm{CH}_{2}\right)_{2} \mathrm{O}\right)$, 4.249 (t, 2H, $\left.\mathrm{CH}_{2} \mathrm{~N}\right), 6.183$ (s, $\left.1 \mathrm{H}, \mathrm{CH}=\mathrm{C}-\mathrm{N}\right)$, 6.979 (m, 1H, ArH), 7.070 (m, 1H, ArH), 7.342 (m, 1H, ArH), 7.426 (m, 1H, ArH). ${ }^{13} \mathrm{C}$ NMR (125 MHz, acetone-d6): $\delta=12.798\left(\mathrm{CH}_{3}\right)$, $\left.41.694\left(\mathrm{CH}_{2} \mathrm{~N}\right), \quad 54.972 \quad\left(\mathrm{CH}_{2}\right)_{2} \mathrm{~N}\right), \quad 58.754$ $\left.\left(\mathrm{CH}_{2} \mathrm{~N}\right), 67.475\left(\mathrm{CH}_{2}\right)_{2} \mathrm{O}\right), 100.615(\mathrm{CH}=\mathrm{C}-\mathrm{N})$, 109.851 (ArC), 119.794 (ArC), 120.198 (ArC), 
120.970 (ArC), 129.264 (ArC), 137.30 (ArC), $137.697(\mathrm{CH}=C-\mathrm{N})$. MS (EI): $m / z 244[\mathrm{M}]^{+}$.

In the second step, 1-(2- $(N-$ morpholino)ethyl)-2-methylindole was dissolved into the ionic liquid and the solution was heated to $150{ }^{\circ} \mathrm{C}$ for $10 \mathrm{~min}$. 4Methoxybenzoyl chloride was then introduced to the solution and the reaction mixture was heated under an argon atmosphere at $150{ }^{\circ} \mathrm{C}$ with vigrous magnetic stirring for $20 \mathrm{~min}$. After cooling down to room temperature, the reaction mixture was washed with diethyl ether, neutralized using aqueous $\mathrm{KOH}$ solution. The pravadoline product was extracted into toluene, dried over $\mathrm{Na}_{2} \mathrm{SO}_{4}$. Toluene and any ether residue was removed by a rotovap at 30 ${ }^{\circ} \mathrm{C}$. The product was dried under vacuum at room temperature for $24 \mathrm{~h}$, purified by recrystalization to achieve isolated yield, and analyzed by HPLC-MS, ${ }^{1} \mathrm{H}$ and ${ }^{13} \mathrm{C}$ NMR.

${ }^{1} \mathrm{H}$ NMR (500 MHz, acetone-d6): $\delta=2.480$ $\left(\mathrm{m}, 4 \mathrm{H},\left(\mathrm{CH}_{2}\right)_{2} \mathrm{~N}\right), 2.570$ (s, 3H; $\left.\mathrm{CH}_{3}\right), 2.724$ (m, 2H, $\left.\mathrm{CH}_{2} \mathrm{~N}\right), 3.594\left(\mathrm{~m}, 4 \mathrm{H},\left(\mathrm{CH}_{2}\right)_{2} \mathrm{O}\right), 3.887$ $\left(\mathrm{s}, 3 \mathrm{H}, \mathrm{CH}_{3} \mathrm{O}\right), 4.365\left(\mathrm{t}, 2 \mathrm{H}, \mathrm{CH}_{2} \mathrm{~N}\right), 7.021(\mathrm{~m}$, 3H, ArH), 7.168 (m, 1H, ArH), 7.397 (m, 1H, ArH), 7.487 (m, 1H, ArH), 7.726 (m, 2H, ArH). ${ }^{13} \mathrm{C}$ NMR (125 MHz, acetone-d6): $\delta=$ $12.676 \quad\left(\mathrm{CH}_{3}\right), \quad 41.903 \quad\left(\mathrm{CH}_{2} \mathrm{~N}\right), \quad 54.915$ $\left.\left(\mathrm{CH}_{2}\right)_{2} \mathrm{~N}\right), \quad 55.807 \quad\left(\mathrm{CH}_{2} \mathrm{~N}\right), \quad 58.294 \quad\left(\mathrm{CH}_{3} \mathrm{O}\right)$ $\left.67.443\left(\mathrm{CH}_{2}\right)_{2} \mathrm{O}\right), 100.585(\mathrm{CH}=\mathrm{C}-\mathrm{N}), 114.216$

(ArC), 114.430 (ArC), 121.329 (ArC), 121.677

(ArC), 122.504 (ArC), 128.241 (ArC), 132.003

(ArC), 134.927 (ArC), 136.844 (ArC), 144.282
$(\mathrm{CH}=C-\mathrm{N}), 163.474(\mathrm{ArC}-\mathrm{O}), 191.380(\mathrm{C}=\mathrm{O})$. MS (ESI): $m / z, 378[\mathrm{M}]^{+}$.

\section{RESULTS AND DISCUSSION}

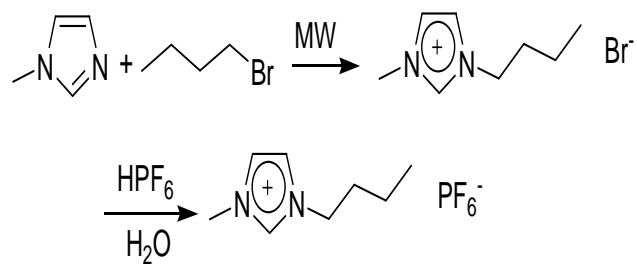

Scheme 1. Synthesis of the1-butyl-3 methylimidazolium hexafluorophosphate

([BMIM] $\left[\mathrm{PF}_{6}\right]$ ) ionic liquid.

The ionic liquid was synthesized according to a previously reported procedure [10]. In view of the green chemistry, it was decided to explore the synthesis of 1-butyl-3methylimidazolium bromide ([BMIM][Br]) using microwave irradiation under solvent-free condition. The anion metathesis reaction of 1butyl-3-methylimidazolium bromide with hexafluorophosphoric acid was then carried out to prepare 1-butyl-3-methylimidazolium hexafluorophosphate ([BMIM] $\left[\mathrm{PF}_{6}\right]$ ), according to a literature procedure (Scheme 1) [11,12]. 1-Hexyl-3-methylimidazolium

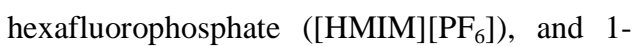
octyl-3-methylimidazolium hexafluorophosphate ([OMIM] $\left.\left[\mathrm{PF}_{6}\right]\right)$ were also synthesized using similar procedure. The ionic liquids were characterized using ${ }^{1} \mathrm{H}$ and ${ }^{13} \mathrm{C}$ NMR, and MS, which were in good agreement with the literature $[10,11]$.

\section{Trang 82}




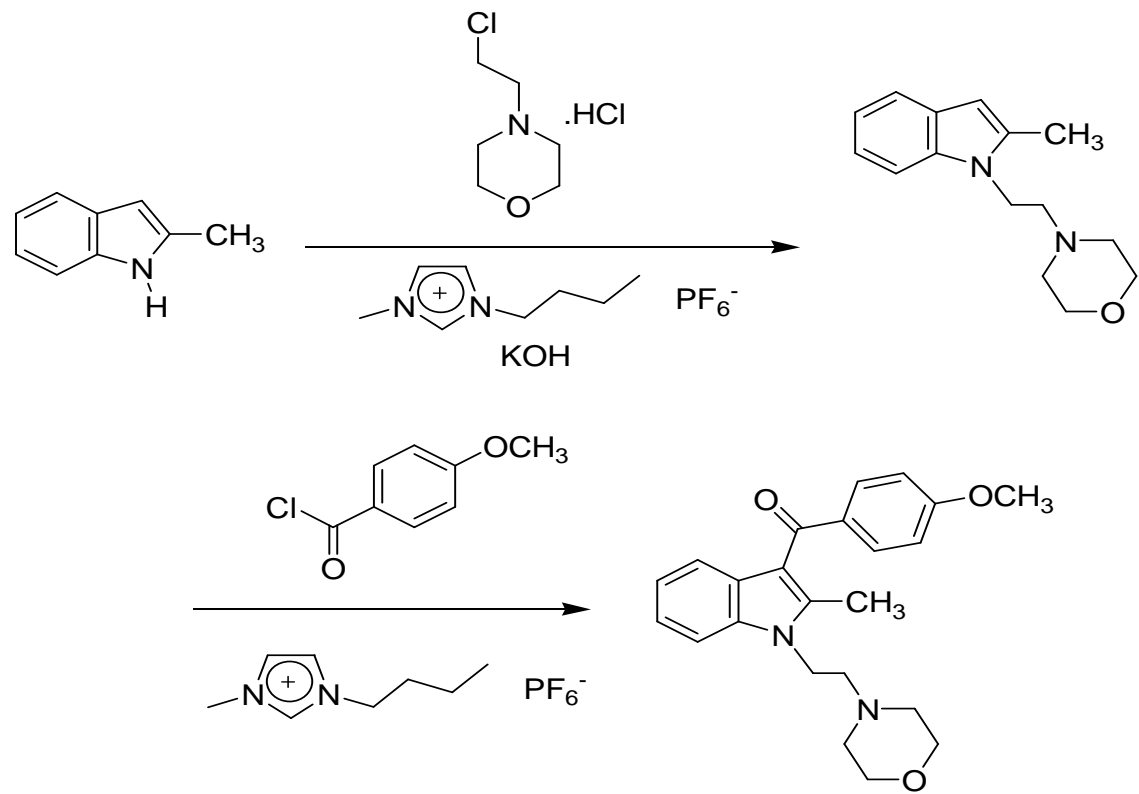

Scheme 2. The synthesis of pravadoline in the $[\mathrm{BMIM}]\left[\mathrm{PF}_{6}\right]$ ionic liquid.

The $[\mathrm{BMIM}]\left[\mathrm{PF}_{6}\right]$ ionic liquid was evaluated for their suitability as reaction solvent for the synthesis of pravadoline. The first step of the process was the reaction between $1-(N$ morpholino)-2-chloroethane hydrochloride and 2-methylindole to form 1-(2- $(N-$ morpholino)ethyl)-2-methylindole as the principal product. The second step was the Friedel-Crafts acylation of 4-methoxybenzoyl chloride with the intermediate product from the first step (Scheme 2). The first reaction was normally carried out in DMF or DMSO, in the presence of a strong base such as $\mathrm{NaH}, \mathrm{NaNH}_{2}$, $\mathrm{CH}_{3} \mathrm{ONa}$, KOH, or $\mathrm{NaOH}$, respectively $[13,14]$. These conventional processes suffer from the disadvantage that the solvent is difficult to separate from the product, is usually lost to the environment, is noxious (in the case of DMSO), and has an unpleasant odor [2].
Using the $[\mathrm{BMIM}]\left[\mathrm{PF}_{6}\right]$ ionic liquid as solvent for the reaction in conjunction with $\mathrm{KOH}$ as a base,

1-(2-(N-morpholino)ethyl)-2methylindole was achieved in an isolated yield of $80 \%$. The product was fully characterized using ${ }^{1} \mathrm{H}$ and ${ }^{13} \mathrm{C}$ NMR, and MS. Full investigation of the first step was previously published by our research group $[8,9]$.

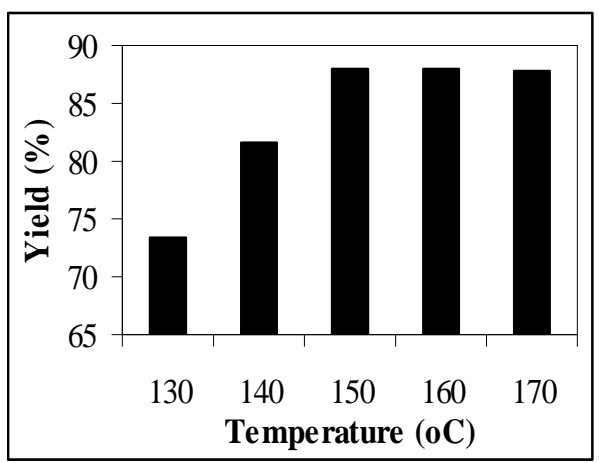

Figure 1. Effect of reaction temperature on reaction yield 
The work in this paper focused on the synthesis of pravadoline using the FriedelCrafts acylation reaction between 1-(2- $(N-$ morpholino) ethyl)-2-methylindole and 4methoxybenzoyl chloride in ionic liquids. Initial investigation addressed the effect of temperature on reaction yield, have carried out the reaction in $[\mathrm{BMIM}]\left[\mathrm{PF}_{6}\right]$ in $20 \mathrm{~min}$ at 130 ${ }^{\circ} \mathrm{C}, 140{ }^{\circ} \mathrm{C}, 150{ }^{\circ} \mathrm{C}, 160{ }^{\circ} \mathrm{C}$, and $170{ }^{\circ} \mathrm{C}$, respectively. It was observed that the temperature had a significant effect on the reaction yield. The reaction carried out at 150 ${ }^{\circ} \mathrm{C}$ proceeded readily, with a yield of $88 \%$ being obtained. As expected, decreasing the temperature to $130{ }^{\circ} \mathrm{C}$ resulted in a significant drop in reaction yield $(73 \%)$. The reaction carried out at $140{ }^{\circ} \mathrm{C}$ could afford a yield of $81 \%$. Interestingly, it was found that the reaction yield remained almost unchanged when the temperature increased from $150{ }^{\circ} \mathrm{C}$ to $160{ }^{\circ} \mathrm{C}$ and $170{ }^{\circ} \mathrm{C}$, respectively (Figure 1 ).

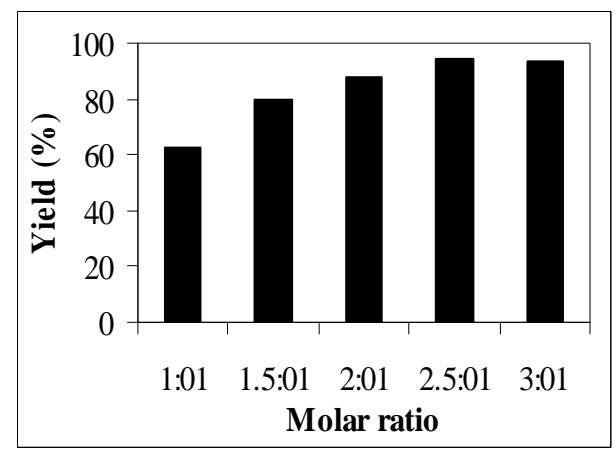

Figure 2. Effect of reagent molar ratio on reaction yield

It was therefore decided to carry out the Friedel-Crafts acylation reaction in the ionic liquid at $150{ }^{\circ} \mathrm{C}$ in further studies. With this result in mind, we then investigated the effect of the 4-methoxybenzoyl chloride: 1-(2- $(N-$ morpholino) ethyl)-2-methylindole molar ratio on the reaction yield. It was observed that the reaction using one equivalent of 4methoxybenzoyl chloride produced the pravadoline product in a yield of only $62 \%$. As expected, increasing the reagent molar ratio of the reagents led to an enhancement in the reaction yield. The reaction using the molar ratio of 1.5:1 afforded the pravadoline in a yield of $79 \%$, while $88 \%$ yield was achieved at the molar ratio of $2: 1$. It was found that the reaction yield could be improved to $94 \%$ at the reagent molar ratio of 2.5:1. However, increasing the ratio to higher than 2.5:1 was found to be unnecessary as the pravadoline yield was not improved any further (Figure 2).

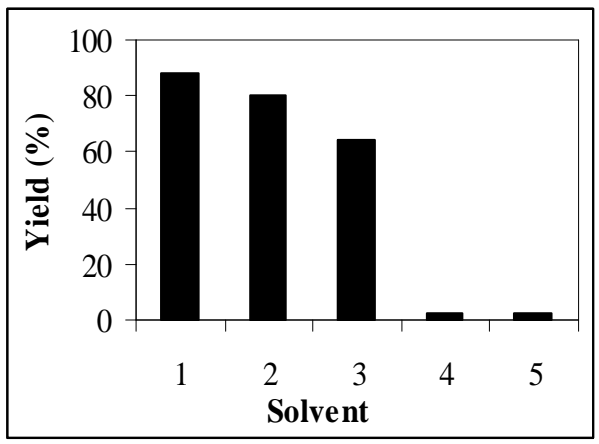

Figure 3. Effect of solvents on reaction yield: [BMIM] $\left[\mathrm{PF}_{6}\right]$ (1), [HMIM][PF 6$]$ (2), [OMIM] $\left[\mathrm{PF}_{6}\right]$ (3), DEF (4), and DMSO (5)

Indoles are known to be fairly reactive in the Friedel-Crafts reaction, and the use of strong Bronsted or Lewis acids is known to polymerize indoles. For example, indole readily dimerizes to 3'-indoyl-2,3dihydroindole in the presence of a catalytic

\section{Trang 84}


quantity of acid [2,15]. The significant advantage of the pravadoline synthesis using ionic liquids as solvents was that no acid catalyst was required for the Friedel-Crafts acylation reaction. Indeed, Yeung and cowokers previously reported that when the Friedel-Crafts acylation of indoles were carried out in acidic ionic liquids containing aluminum chloride, the reaction could occur at room temperature within $18 \mathrm{~h}$ [15]. Other imidazolium-based ionic liquids, including $[\mathrm{HMIM}]\left[\mathrm{PF}_{6}\right]$, and $[\mathrm{OMIM}]\left[\mathrm{PF}_{6}\right]$, were also used as solvents for the reaction. The reaction was carried out in $20 \mathrm{~min}$ at $150{ }^{\circ} \mathrm{C}$, using the reagent molar ratio of $2.5: 1$. It was found that increasing the alkyl chain resulted in a drop in reaction yield, with $80 \%$ yield and $65 \%$ yield being achieved for the case of $[\mathrm{HMIM}]\left[\mathrm{PF}_{6}\right]$ and $[\mathrm{OMIM}]\left[\mathrm{PF}_{6}\right]$, respectively. It should be noted that the acylation reaction carried out in DEF and DMSO failed completely under similar reaction conditions (Figure 3). These results emphasized the advantages of the ionic liquids over conventional organic solvents in the synthesis of pravadoline.

\section{CONCLUSIONS}

In conclusion, an easily accessible ionic liquid, $[\mathrm{BMIM}]\left[\mathrm{PF}_{6}\right]$, was synthesized and characterized using ${ }^{1} \mathrm{H}$ and ${ }^{13} \mathrm{C}$ NMR, and MS. It was found that the ionic liquid could be used as a green solvent for the synthesis of pravadoline, one of non-steroidal drugs. The reaction was also successfully carried out using other imidazolium-based ionic liquids, including $[\mathrm{HMIM}]\left[\mathrm{PF}_{6}\right]$, and $[\mathrm{OMIM}]\left[\mathrm{PF}_{6}\right]$. The significant advantage of the process was that the ionic liquid offered easy product separation. Furthermore, the Friedel-Craft acylation reaction in the second step could be successfully carried out without the need of an anhydrous Lewis acid catalyst. Our results here demonstrate the feasibility of applying ionic liquids as green solvents in the field of organic synthesis. Current research in our laboratory has been directed to the design and the synthesis of several ionic liquids for a wide range of organic transformations, and results will be published in due course. 


\title{
NGHIÊN CÚU SỬ DỤNG CHẤT LỎNG ION HỌ IMIDAZOLIUM LÀM DUNG MÔI XANH CHO PHẢN ÚNG TỔNG HỢP PRAVADOLINE
}

\author{
Phan Thanh Sơn Nam, Lê Vũ Hà
}

Trường Đại học Bách khoa, ĐHQG-HCM

\begin{abstract}
TÓM TĂT: Các chất lỏng ion 1-butyl-3-methylimidazolium hexafluorophosphate

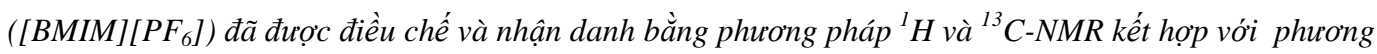
pháp MS. Chất lỏng ion ([BMIM][PF $]$ đã được sủ dụng làm dung môi xanh cho phản ứng tổng hợp pravadoline, một loại thuốc kháng viêm không chứa steroid, với hiệu suất cao mà không cần xúc tác acid Lewis. Phản úng cũng được thực hiện thành công trong các chất lỏng ion họ imidazolim khác, bao gồm 1-hexyl-3-methylimidazolium hexafluorophosphate ([HMIM][PF $]$ ) và 1-octyl-3methylimidazolium hexafluorophosphate ([OMIM][PF $\left.F_{6}\right]$ ). Theo hiểu biết của chúng tôi, đây là lần đầu tiên ở Việt Nam, quá trình tổng hợp pravadoline được nghiên cúu và tiến hành trong dung môi xanh là chất lỏng ion.
\end{abstract}

Tù̀ khóa:

\section{REFERENCES}

[1]. D. R. Haubrich, S. J. Ward, E. Baizman, J. Pharmacol. Exp. Ther. 255, 511 (1990).

[2]. M. J. Earle, P. B. McCormac, K. R. Seddon, Green Chem., 2, 261 (2000).

[3]. K. Okubo, M. Shirai, C. Yokoyama, Tetrahedron Lett., 43, 7115 (2002).

[4]. G. A. Sheldon, Green Chem., 7, 267 (2005).

[5]. J. Dupont, R. F. D. Souza, P. A. Z. Suarez, Chem. Rev., 102, 3667 (2002).

[6]. C. Chiappe, D. Pieraccini, J. Phys. Org. Chem., 18, 275 (2005).

[7]. Duong Thi Anh Tuyet, Le Ngoc Thach, 'Synthesis of room temperature ionic liquid alkylpyridinium bromide in green chemistry conditions, National Conference on Science \& Technology of Organic Chemistry, 721 (2007).
[8]. Phan Thanh Son Nam, Tong Thu Phuong, Vietnam J. Sci. Tech., 48, 53 (2010).

[9]. Phan Thanh Son Nam, Tran Duc My, Vietnam J. Chem, in press (2010).

[10]. Phan Thanh Son Nam, Nguyen Thi Hoai An, Le Thi Ngoc Diem, Vietnam J. Chem., 47, 566 (2009).

[11].A. de la Hoz, A. D. Ortiz, A. Moreno, Chem. Soc. Rev., 34, 164 (2005).

[12].C. O. Kappe, Angew. Chem. Int. Ed., 43, 6250 (2004).

[13]. H. Heaney, S. V. Ley, Org. Synth., 6, 104 (1988).

[14]. M. R. Bell et al., J. Med. Chem., 34, 1099 (1991).

[15]. K. Yeung, M. E. Farkas, Z. Qiu, Z. Yang, Tetrahedron Lett., 43, 5793 (2002).

\section{Trang 86}

